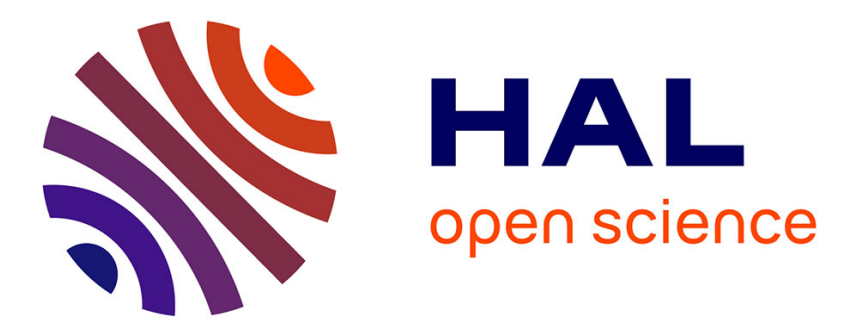

\title{
Biological Cells Proliferation in Microwave Microsystems
}

François Artis, David Dubuc, Marie-Charline Blatché, Katia Grenier

\section{To cite this version:}

François Artis, David Dubuc, Marie-Charline Blatché, Katia Grenier. Biological Cells Proliferation in Microwave Microsystems. IEEE International Microwave Symposium, 2012 IEEE MTT-S, Jun 2012, Montréal, Canada. pp.1-3. hal-00762137

\section{HAL Id: hal-00762137 https://hal.science/hal-00762137}

Submitted on 6 Dec 2012

HAL is a multi-disciplinary open access archive for the deposit and dissemination of scientific research documents, whether they are published or not. The documents may come from teaching and research institutions in France or abroad, or from public or private research centers.
L'archive ouverte pluridisciplinaire HAL, est destinée au dépôt et à la diffusion de documents scientifiques de niveau recherche, publiés ou non, émanant des établissements d'enseignement et de recherche français ou étrangers, des laboratoires publics ou privés. 


\title{
Biological Cells Proliferation in Microwave Microsystems
}

\author{
François Artis $^{1,2}$, David Dubuc ${ }^{1,2}$, Charline Blatche ${ }^{1,2}$, Katia Grenier ${ }^{1,2}$ \\ ${ }^{1}$ CNRS, LAAS, 7. Av. du Colonel Roche, F-31400 Toulouse, France \\ ${ }^{2}$ Univ. de Toulouse, LAAS, F-31400 Toulouse, France \\ fartis@1aas.fr, dubuc@laas.fr,grenier@laas.fr
}

\begin{abstract}
This paper presents the biological compatibility of a microwave analyzing microsystem of living cells through the indicator of cells proliferation. The cells under investigation correspond to adherent cells of Normal Rat Kidney (NRK). In a first time, both their adhesion and proliferation into the highfrequency-based micro-device have been successfully obtained. In a second step, microwave signals have been applied at different power levels. Experimental studies demonstrate that microwave power levels up to $+8,6 \mathrm{dBm}$ do not impact cells proliferation.
\end{abstract}

Index Terms - Biological effects, Biosensor, Cell proliferation, Coplanar wave-guide, Microwaves.

\section{INTRODUCTION}

For a decade, microtechnologies and microfluidics have enabled the development of biological chips at the cellular and molecular levels [1]. Towards the elaboration of lab-on-chips, the investigation of integrated sensors is mandatory. Among the various developed sensing techniques, optical, mechanical ones for instance, microwave signals may also be used, which confers to the analyzing technique the advantages of being contact-less and marker-less. The employment of such a detection scheme and the corresponding micro-devices nevertheless imply to evaluate their biocompatibility.

Biocompatibility is concerned in terms of:

(1) cells adhesion capabilities. These imply to develop technological process flow, which favors cell adhesion and proliferation.

(2) cells proliferation under and after a microwave power stress.

If the assessment of biocompatibility of various biomaterials (such as yeasts, blood red cells, algae, enzymes, cells [2-5]) in microsystems and/or integrated circuits [6] is quite mature, the biocompatibility in microwave (i.e. under electromagnetic stresses) microsystems constitutes a really recent issue [7].

This paper presents the study of biocompatibility of living cells within a microfluidic reservoir placed over a coplanar waveguide.

The cells used in our case correspond to Normal Rat Kidney ones (NRK). Their choice has been driven by two reasons: (1) for their ability to resist to in-vitro culture conditions and (2) due to the fact that they are adherent [6]. These NRK cells are also immortalized ones, which means that they may not stop proliferating as normal cells do through apoptosis.
The indicator chosen in our study is the cells proliferation or more exactly the ability for cells to divide again after a microwave stress. To the best of our knowledge, we report, for the first time at the micro scale, the impact of the MW power excitation inside a biosensor dedicated to living cells probing.

\section{DESCRIPTION OF THE HF-BASED MICROSENSOR}

As presented with the picture of Fig. 1, the device consists in a coplanar waveguide with a microfluidic tank perpendicularly placed on the top, in order to well localize the adherent cells and prevent any liquid and pollution on the coplanar accesses.

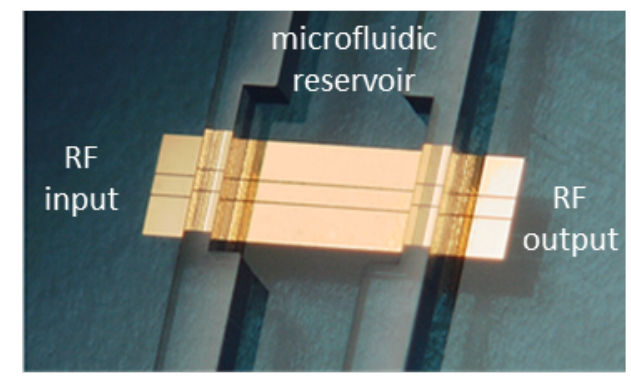

Fig. 1. Photography of the micro-CPW device with a SU8-tank placed on top

The waveguide is obtained through a lift-off process with the superposition of a titanium flash layer and a $300 \mathrm{~nm}$-thick gold layer on a quartz substrate. The line exhibits widths of the central conductor and slots of $150 \mu \mathrm{m}$ and $15 \mu \mathrm{m}$ large respectively, in order to match a $50-\Omega$ impedance in air.

The walls of the tank are made of SU8 photoresist. The width of the tank corresponds to $1,5 \mathrm{~mm}$, with a height close to $250 \mu \mathrm{m}$. The fluidic volume is less than $2 \mu \mathrm{L}$. With such a volume and the open tank configuration, some cares are taken to avoid strong evaporation, which may be critical for the NRK cells in terms of dehydration and heat shock.

\section{BIOLOGICAL PROTOCOL}

A specific biological protocol to make the cells adhering on the device and to control the viability of the cells through their proliferation has been defined.

First, the manufactured micro-device is sterilized in a solution of $70^{\circ}$-ethanol. The sample is then placed into traditional bio-well plates with NRK cells in solution. The used biological medium corresponds to a mixture of 
Dulbecco's Modified Eagle's Medium (DMEM), which provides the necessary nutrients to cells, as well as $10 \%$ of fetal calf serum (FCS), which offers the growth factors, antibiotics to prevent bacterial contamination and finally a buffer employed to maintain the $\mathrm{pH}$. The entire plate is then placed into an incubator, which provides the adequate condition of cells proliferation, i.e. a constant temperature of $37^{\circ} \mathrm{C}$ and $5 \%$ of $\mathrm{CO}_{2}$. This step permits the seeding of the cells on the surface of the microwave biosensor and the initialization of their proliferation. After incubation, which warrants the adhesion of few cells in the fluidic tank, the cells are firstly observed with a microscope at the day called D0. The cells are then observed twice a day during three days after the D0 day.

To evaluate the cells proliferation, the developed observation method is based on the determination of the surface occupied by the NRK cells, as presented in Fig. 2. We based our counting method on the assessments that the area occupied by the cells is proportional to their number and that the cells have enough space not to be squeezed. By considering the surface occupied by the cells (cf. Fig. 2) divided by the whole surface area on top of the $\mathrm{CPW}$ in the microfluidic zone, we have defined a proliferation ratio, which is normalized with respect to D0 and considered versus time.
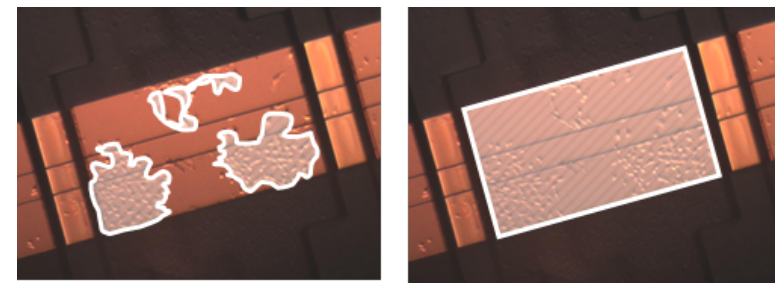

Fig. 2. Delimitations of cells clusters and the entire CPW area

The normalized cells proliferation versus time is indicated in Fig. 3 and indicates a cell cycle of about 1,5 day (cells doubling at the end of the mitosis).

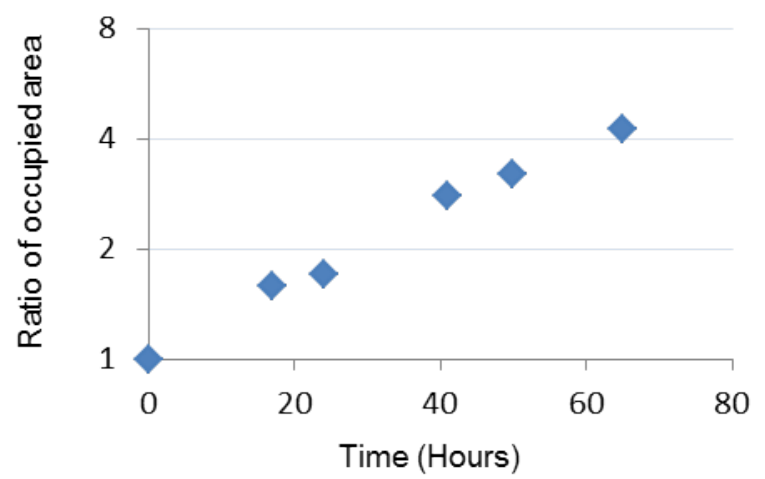

Fig. 3. Cell proliferation in the microwave biosensor without any applied HF signal

The biological protocol successfully yields the correct adhesion of cells into the HF-based biosensor and their proliferation. Based on this protocol, High-Frequency signals were applied.

\section{MICROWAVE EXPERIMENTS}

\section{A. Microwave application protocol and test setup}

For the microwave test setup, an ANRITSU MG3694B signal generator is connected at the input of the micro-device through a coaxial cable ended by a coplanar probe. The generator is used to apply specific power levels on the device at a single frequency, $20 \mathrm{GHz}$ in our case, as it corresponds to the maximum absorption of the biological medium. A power meter ANRITSU ML2437A is also connected at the output of the coplanar line to collect the output power level of the micro-device.

Three different power levels are tested in addition to a control sample, which is submitted to the measurement protocol without any HF signal application. The three levels correspond to $-10 \mathrm{dBm},+5 \mathrm{dBm}$ and $+20 \mathrm{dBm}$ respectively.

The microwave application protocol is as it follows. After the optical observation of the sample at D0, the samples are submitted to the microwave signal for 10 minutes. They are then placed again into the incubator with sufficient biological medium to prevent any lack. The samples are then optically observed periodically. All pictures are treated as previously indicated in the biological protocol.

\section{B. EM Simulations}

EM simulations have been performed with the 3D EM software HFSS in order to get a qualitative assessment of the wave attenuation in the medium. Fig. 4 presents a corresponding result. The electrical field rapidly attenuates in the lossy medium and dominates in the vicinity of the coplanar slots.

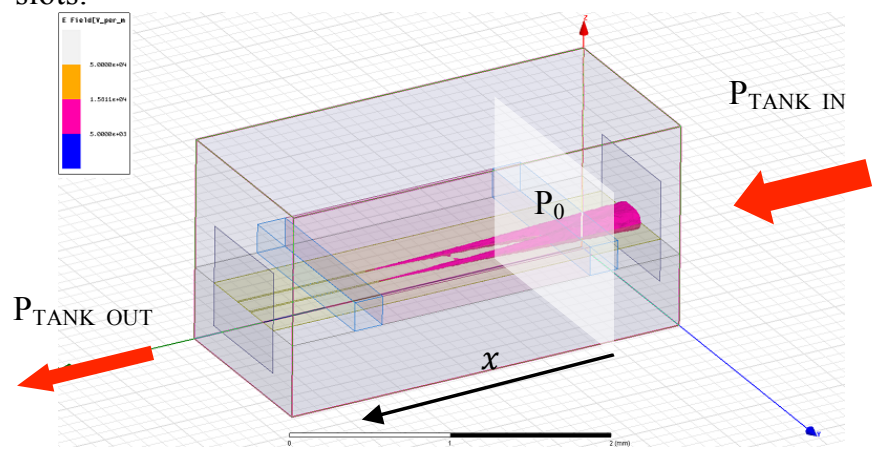

Fig. 4. Electromagnetic field distribution in the SU8-tank

With such simulations, we have determined that the attenuation $\mathrm{P}(\mathrm{x})$ of the power is position dependent in the tank and follows the equation (1):

$$
P(x)=P_{0} \cdot e^{-2,34 \cdot x}
$$

where $x$ and $P_{0}$ correspond to the position in the width of the tank and the input power at the beginning of the fluidic reservoir, respectively. This formula and the simulations have allowed us to estimate the power at different locations in the biological medium. We would like to outline that the absorbed power is mainly located in the biological medium rather than in the cells, due to the high ratio: E.M. energy volume / cells' 
volume. As far as the bio-compatibility of cells proliferation under microwave power stress is concerned, we did not look at the power absorbed by the bio sample and focused on the assessment of the absolute maximum rating in term of RF power to ensure cells proliferation. In this scope, in order to obtain a good accuracy, we have discretized the fluidic tank in four parts, which correspond to specific average power levels, as indicated in Fig. 5.

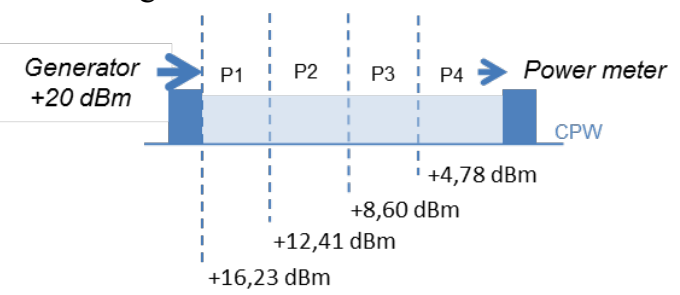

Fig. 5. Microwave power levels distribution in the microfluidic tank with $+20 \mathrm{dBm}$ as an input power

\section{RESULTS AND DISCUSSION}

Fig. 6 presents the observed normalized number of cells in part 1 of the micro-devices versus time, for the $-10 \mathrm{dBm}$ and $+5 \mathrm{dBm}$ applied power levels, as well as for the control sample. No significant impact of HF signals has been encountered, as all the curves are very similar and conform to the expected proliferation kinetic. This result proves the correct biocompatibility, regarding cell proliferation, under this range of frequency and power operation.

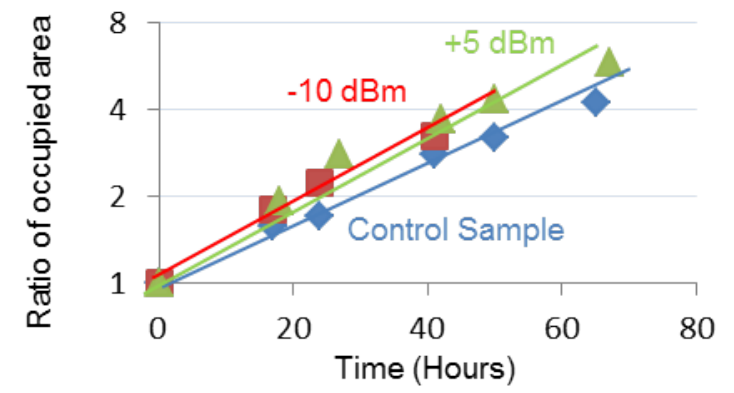

Fig. 6. Cell proliferation for HF micro-devices submitted to $-10,+5$ $\mathrm{dBm}$, as well as the control sample

As far as the $+20 \mathrm{dBm}$ level is used for the generator, the results obtained in the three first different parts of the microfluidic reservoir are indicated in Fig. 7.

From this figure, we can notice that cells submitted to $+16,2$ and $+12,4 \mathrm{dBm}$ totally stopped proliferating (the ratio remains flat for several hours), whereas those located in the third section of the channel are always growing. After 30 and 40 hours in the case of $+12,4$ and $+16,2 \mathrm{dBm}$ respectively, the cells seem to grow again (as indicated in dotted lines). This "regrown effect" corresponds in fact to a parasitic effect, due to peripheral cells, located at the edges of the device, which were not submitted to the microwave signal and migrate towards low cells concentrated areas. This also explains the time shift of this effect (close to 10 hours) between the second and first part of the reservoir.

Moreover, the proliferation behavior for the $+8,6 \mathrm{dBm}$ zone is in good agreement with our precedent measurements at lower power levels (cf. Fig. 6). It should be noticed that additional experiments have demonstrated that these results do not result from thermal effect.

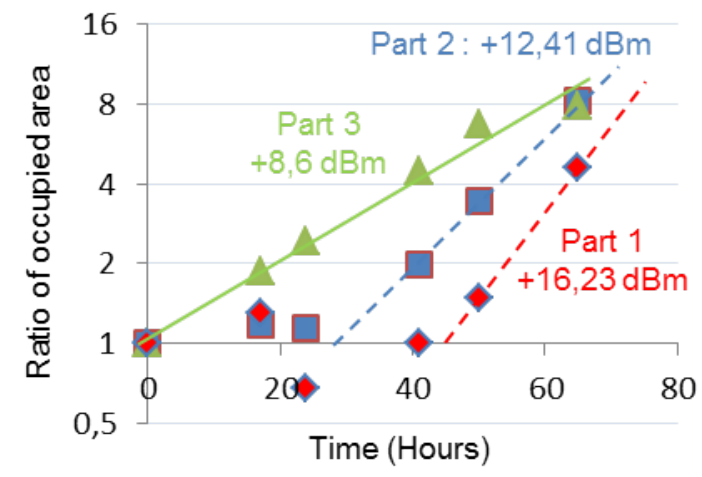

Fig. 7. Cell proliferation into the micro-device at different locations, with $+20 \mathrm{dBm}$ as an input power

\section{CONCLUSIONS}

Microwave biosensing at the cells and molecules level constitutes a promising approach for new biological and medical analyzing tools. The corresponding micro-devices require consequently to be evaluated in terms of biocompatibility and limitations. We have assessed in this paper the compatibility of coplanar lines with a microfluidic reservoir placed on top, with respect to the proliferation indicator of adherent NRK cells. Both adhesion and proliferation of cells were well realized at the microscale and the application of HF signals exhibiting a power level equal to or lower than $+8,6 \mathrm{dBm}$ did not affect or stop the cells proliferation.

HF microsystems are thus in excellent adequacy for noninvasive biological analysis at very low power levels. Such devices may also be suitable for microdosimetry investigations at the cellular and molecular levels.

\section{REFERENCES}

[1] G. M. Whitesides, "The origins and future of microfluidics," Nature, Vol. 442, pp. 368-373, 2006

[2] G. Sajin et al., "Effects of low power microwave radiation on human blood red cell," IEEE MTT-S Int., vol. 1, pp. 543-546, 1994

[3] J.H. Monteiro et al., "Effect of microwave fields on the growth rate and mitosis of a single cell in spirogyra algae," International Conference on Microwave 2008, pp. 790-791, 2008

[4] V. Vojisavljevic et al., "Low intensity microwave radiation as modulator of the L-lactate dehydrogenase activity," Medical and Biological Engineering and Computing, 2010 (Review)

[5] P. Merola et al., "Proliferation and Apoptosis in a Neuroblastoma Cell Line Exposed to $900 \mathrm{MHz}$ Modulated Radiofrequency Field," Bioelectromagnetics, Vol. 27, pp. 164-171, 2006

[6] S. B. Prakash, P. Abshire, "Tracking cancer cell proliferation on a CMOS capacitance sensor chip," Biosensors and Bioelectronics, vol. 23, pp. 1449-1457, 2008

[7] C. Merla et. al., "Real-Time RF Exposure Setup Based on a Multiple Electrode Array (MEA) for Electrophysiological Recording of Neuronal Networks," IEEE T-MTT, Vol.59, n³, pp. 755-762, March 2011 